Section Editor

Mitchell S.V. Elkind, MD, MS

\title{
Teaching NeuroImages: IgG4-related orbital disease and enlargement of the trigeminal nerve branches
}

Romain Deschamps, MD Lydia Deschamps, MD Catherine Vignal, MD Marc Putterman, MD Olivier Galatoire, MD Olivier Gout, MD

Correspondence to Dr. Romain Deschamps: rdeschamps@fo-rothschild.f

Download teaching slides: www.neurology.org

Figure 1 Brain MRI findings

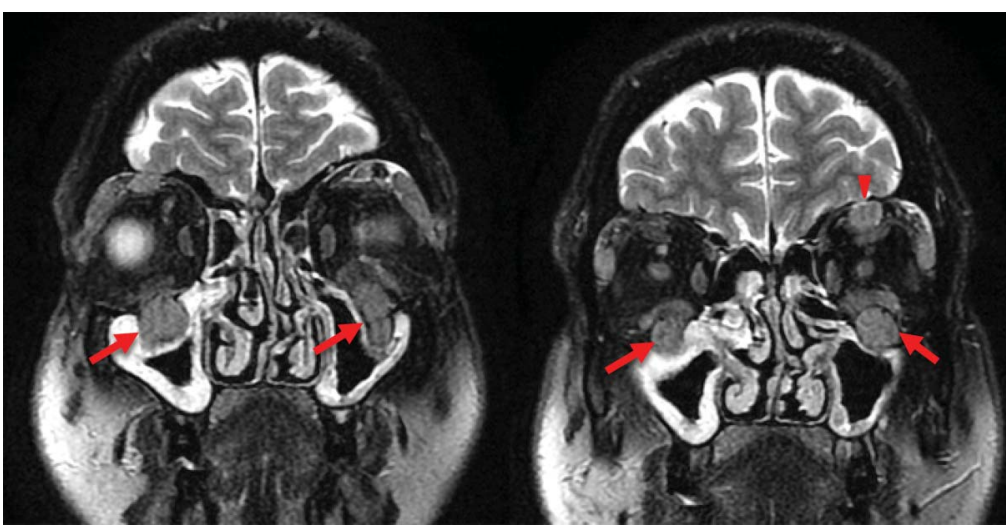

STIR fat-saturated T2-weighted coronal MRI demonstrates thickening of bilateral infraorbital (arrow; adjacent to the enlarged inferior rectus) and left frontal (arrowhead; near the swollen left superior rectus and levator complex) nerves.

Figure 2 Pathologic findings of the biopsy from the left infraorbital canal

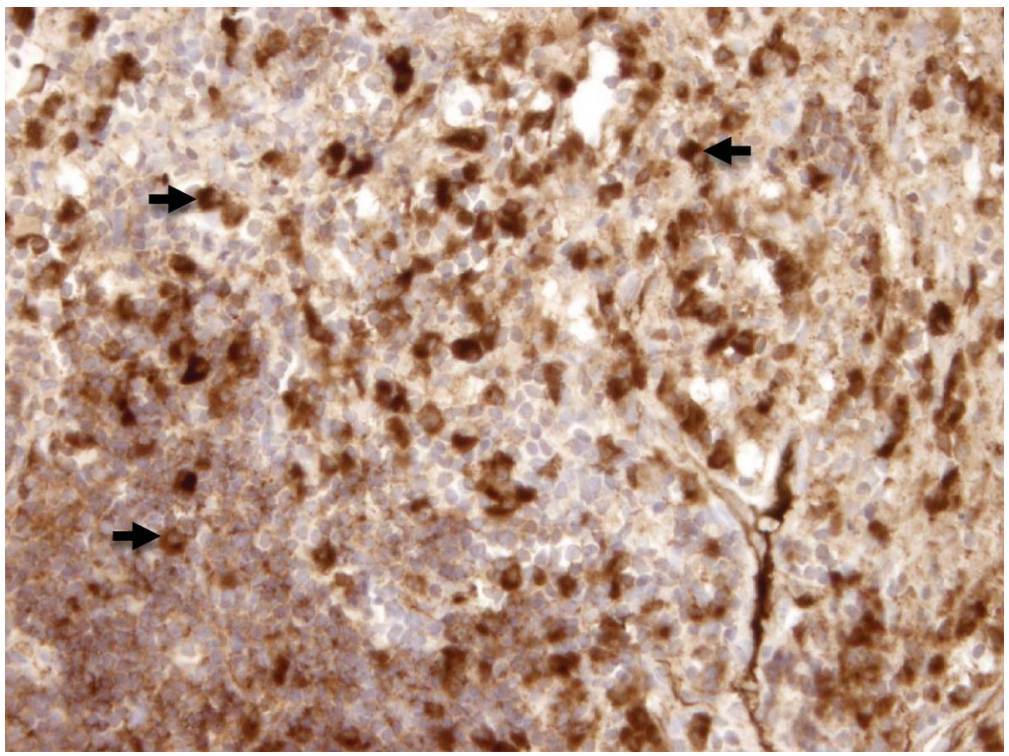

Immunoglobulin G 4 immunohistochemistry shows numerous plasma cells stained positive (arrows) (immunoperoxidase, original magnification $\times 200$ ).

A 54-year-old man had a 5-year history of painless bilateral eyelid swelling, proptosis, and diplopia. MRI showed enlargement of extraocular muscles, lacrimal gland, and divisions of the trigeminal nerve (figure 1). Biopsy from the left infraorbital canal demonstrated lymphoplasmacytic infiltrate and fibrosis. Mean number of immunoglobulin G (IgG)4+ cells was 155 per high-power field and ratio of $\operatorname{IgG} 4+/ \operatorname{IgG}+$ cells was $89 \%$ (figure 2 ).

From the Departments of Neurology (R.D., O. Gout) and Ophthalmology (C.V., O. Galatoire), Fondation Ophtalmologique Adolphe de Rothschild; Department of Pathology (L.D.), Bichat Hospital, APHP; and Department of Pathology (M.P.), Necker-Enfants Malades Hospital, APHP, Paris, France. Go to Neurology.org for full disclosures. Funding information and disclosures deemed relevant by the authors, if any, are provided at the end of the article. 
Serum IgG4 concentration was $878 \mathrm{mg} / \mathrm{dL}$ (normal range 4-86 mg/dL). Symptoms resolved with steroids. The patient relapsed during tapering and azathioprine was added. IgG4-related disease is characterized by IgG4-positive cells and lymphocyte infiltration into various organs, including orbital tissues. Thickening of branches of the trigeminal nerve is highly suggestive of IgG4-related disease. ${ }^{1,2}$

\section{AUTHOR CONTRIBUTIONS}

Dr. R. Deschamps: corresponding author; drafting/revising the manuscript for content, including medical writing for content. Drs. L. Deschamps, Vignal, Putterman, Galatoire, and Gout: drafting/revising the manuscript for content, including medical writing for content.

\section{STUDY FUNDING}

No targeted funding reported.

\section{DISCLOSURE}

The authors report no disclosures relevant to the manuscript. Go to Neurology. org for full disclosures.

\section{REFERENCES}

1. Toyoda K, Oba H, Kutomi K, et al. MR imaging of IgG4related disease in the head and neck and brain. AJNR Am J Neuroradiol 2012;33:2136-2139.

2. Ohshima K, Sogabe Y, Sato Y. The usefulness of infraorbital nerve enlargement on MRI imaging in clinical diagnosis of IgG4-related orbital disease. Jpn J Ophthalmol 2012;56: 380-382. 


\section{Neurology}

\section{Teaching NeuroImages: IgG4-related orbital disease and enlargement of the trigeminal nerve branches}

Romain Deschamps, Lydia Deschamps, Catherine Vignal, et al. Neurology 2013;81;e117-e118

DOI 10.1212/WNL.0b013e3182a82393

\section{This information is current as of October 7, 2013}

\section{Updated Information \& Services}

Supplementary Material

\section{References}

Subspecialty Collections

Permissions \& Licensing

Reprints including high resolution figures, can be found at: http://n.neurology.org/content/81/15/e117.full

Supplementary material can be found at: http://n.neurology.org/content/suppl/2013/10/06/81.15.e117.DC1

This article cites 2 articles, 1 of which you can access for free at: http://n.neurology.org/content/81/15/e117.full\#ref-list-1

This article, along with others on similar topics, appears in the following collection(s):

All Immunology

http://n.neurology.org/cgi/collection/all_immunology

Cranial neuropathy

http://n.neurology.org/cgi/collection/cranial_neuropathy

Diplopia (double vision)

http://n.neurology.org/cgi/collection/diplopia_double_vision MRI

http://n.neurology.org/cgi/collection/mri

Orbit

http://n.neurology.org/cgi/collection/orbit

Information about reproducing this article in parts (figures,tables) or in its entirety can be found online at:

http://www.neurology.org/about/about_the_journal\#permissions

Information about ordering reprints can be found online:

http://n.neurology.org/subscribers/advertise

Neurology ${ }^{\circledR}$ is the official journal of the American Academy of Neurology. Published continuously since 1951, it is now a weekly with 48 issues per year. Copyright () 2013 American Academy of Neurology. All rights reserved. Print ISSN: 0028-3878. Online ISSN: 1526-632X.

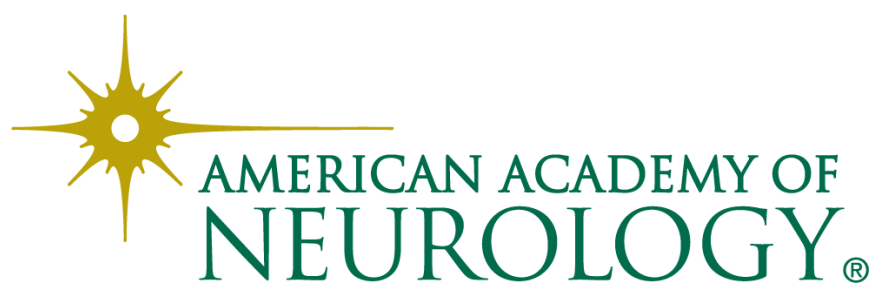

